\title{
Perceptions of Auditor Independence in Libyan Audit Market
}

\author{
Khaled Hamuda ${ }^{1}$ \& Nedal Sawan ${ }^{2}$ \\ ${ }^{1}$ Al-Aziza Institute, Libya \\ ${ }^{2}$ Liverpool Business School, United Kingdom \\ Correspondence: Nedal Sawan, Liverpool Business School, United Kingdome. Tel: 0044-776-584-2941. E-mail: \\ ne2000dal@hotmail.com
}

Received: September 19, 2013 Accepted: December 2, 2013

Online Published: January 23, 2014

doi: $10.5539 /$ ibr.v7n2p120

URL: http://dx.doi.org/10.5539/ibr.v7n2p120

\begin{abstract}
This paper attempts to examine the adverse circumstances of auditing, assess the current status and gauge the perceptions of the auditor independence in Libya. It aims to investigate the extent to which audit firms and the Libyan Accountants and Auditors Association (LAAA) play an important role in developing the profession of auditing and enhances auditor independence. The study also indicates a view that, to improve and develop the accounting and auditing profession in general, and to enhance the level of the perception of auditor independence in particular, the LAAA as a professional body should have more power and authority in the Libyan audit market.

Data were collected by two methods, a questionnaire survey (quantitative) and a number of semi-structured interviews (qualitative) to give both triangulation and amplification. The questionnaire was analysed using both conventional comparative statistics and multivariate methods. The sample of respondents comprised three groupings: accounts managers, financial managers and internal auditors working in Libyan public companies; managing partners, partners, audit supervisors and auditors working in audit firms in Libya; and controllers working for the Libyan Association of Auditors and Accountants (LAAA).

The results of the study indicate two groups supported the proposition that the LAAA should adopt international auditing and accounting standards to improve the perception of auditor independence. More important, public companies and audit firms preferred that there should be a law or rule to require public companies to disclose in the financial statements the amount of audit and non-audit services fees paid.
\end{abstract}

Keywords: Libya, accounting profession, developing countries, auditor independence, LAAA, public companies, audit firms

\section{Introduction}

Auditor independence has been the subject matter of professional and academic debate in both developed and developing countries, for a long period of time (Abu Bakar, Rahman, \& Rashid, 2005). Libya is a developing country undergoing a radical programme of social and economic improvement. After the discovery of oil in the mid twentieth century, Libya began to experience accelerated economic growth, with concomitant growth in the accounting profession. Oil exportation has been responsible for the growth of other activities such as investment, the flow of goods into and out of the country, agriculture, industry and other related services Bait-El-Mal (2000). This burgeoning of different activities has led to the improvement of accounting practice in Libya. Therefore, with strengthening economic and business conditions in the country, the number of users of financial information has increased and, hence, there is a pressing need to develop a policy for enhancing the role and the credibility of the audit profession in Libya.

\section{Literature Review}

Although there have short studies recently dealing with the Libyan Accountants and Auditors Association and the auditor independence in Libya, however, the topic still raises interest and calls for further and more in-depth research. The following provides an overview of the key literature in order to gain a deeper understanding of the topic under consideration.

\subsection{Auditor Independent Status in Libya}

It is essential that the auditor should not let his association with management affect his audit in any way; nor, of 
course, ought to be unaware of anything which may be construed as compromising his independence in any way. Higson (2003) found that:

\section{"If an auditor is not independent, one would presume that the audit is a waste of time and that the figures in the financial statements may be meaningless."}

In many countries professional accountants are barred from being employees of the companies they are auditing but other countries allow the professional accountant to sit on the board of managers and to have a small financial interest Higson (2003). Kilani (1988), indicates that the purpose of safeguarding the auditor's independence, Law No. 116 of 1973, which is still the only law classifying the auditors' work in Libya, prohibits the auditor from combining his status as a chartered accountant with certain activities such as:

1) A ministerial place;

2) A public post, for long or short time, with salary or compensation (unless he is permitted to do so according to the provision of this law);

3) Commercial activities;

4) Any other activities which are not compatible with the audit profession.

\subsection{The Design at Libyan Audit Reports}

The most significant part of the entire audit must be the auditor's statement of his independent and professional audit opinions. The auditor's assessment and adjudication of a company's financial statements is communicated through their audit report Higson (2003) pointed out that:

"As the audit report is the means as by which an auditor communicates the results of the audit to the users of the financial statements, it is the public face of the external audit".

In the majority of those countries which have an organized accounting profession, a certain form for the audit report to be used by everyone in the organization is mandatory. In Libya, however, no such standard audit report form is in use, as the LAAA has yet to recommend the implementation of such a document. However, research that has been carried out in the country has shown that both British and American forms of audit report are used by Libyan accountants (see Bait El-Mal et al., 1973; Kilani, 1988). All Libyan chartered accountants' report using the form model of the American audit report as mentioned below:

"We certify that we have examined the balance sheet of the Libyan National Company for Free Trading as of 31 December, 2000 and statements of trading, profit and loss and retained profits for the year then ended. Our examination was made in accordance with generally accepted auditing standards and accordingly included such tests of all accounting records and such other auditing procedures as we considered necessary in the circumstances. In our opinion, the balance sheet of the company and trading statement, profit and loss and retained profits present fairly the financial position of the company at 31 December, 2000 and the result of its operations for the year then ended, in conformity with generally accepted accounting principles applied on a basis consistent with that of the preceding year.

It may be seen that this is a classically American report. The auditor in his report indicated that the assessment was made in accordance with normally accepted auditing standards and the financial statements of the corporation have been organized in accordance with normally accepted accounting principles. As it is established that the LAAA has not issued any principles or standards of accounting or auditing, this means that American principles and standards should have been followed.

In the UK, the Companies Act 1985 (Note 1) required the auditor to state that his report is based on a reexamination and evaluation of the conclusions drawn from confirmation held in the audit process. The former request the auditors to include in their report a declaration as to their compliance or otherwise with the auditing standards. Furthermore, the auditor should provide with the audit report that the financial statements of the client have been prepared according to the previous act.

\subsection{Audit Profession Ethics}

Traditionally, each profession is in possession of a code of ethics which serves to assure its clients and the wider public of its integrity and responsibilities and which therefore maintains its reputation and the trust which people repose in it. Abbott (1983) stated that:

"Ethics codes are the most concrete cultural form in which professions acknowledge their social obligations."

Consequently, the majority of creditable professional institutions impose a code of ethics giving leadership to 
those who practice as members and their customers. Mautz and Sharaf (1961) pointed out that:

"Ethics behaviour in auditing or any other activity is no more specific application of the general notion of ethical conduct devised by philosophers for men generally. Ethical conduct in auditing draws its justification and basic nature the general theory of ethics".

Kilani (1988) also points out that:

"Not all countries, developed or developing have a formal code of ethics for their accounting profession. However, in countries that do not have formal code of ethics, the professionals may informally agree upon a fairly developed code of ethics".

The situation in Libya is such that the law governing the LAAA requires all auditors to conduct their professional affairs according to the ethics of their profession. However, as such a code of ethics has not yet been established in the country, an academic accountant proposed such a code to the LAAA. This code was taken entirely from the AICPA's code of ethics, and includes similar rules of conduct as in the USA (ibid), abiding by the following principles: independence, integrity and objectivity, a general standard of competence, auditing standards and conformity with accounting principles. In the UK, Companies Act 1985, similarly states that the ethical principles which control the auditor's professional responsibility comprise integrity, objectivity, independence, professional competence and due care, professional behaviour and confidentiality.

\section{Methods and the Sampling Unit}

An aspect of the research that impacts significantly on the quality of the data that is collected is the selection of those who will participate in the research. For this reason Denscombe (2001) strongly recommends that in order to be able to use the best population sample for the research, the researchers should be able to make their own selection. Sekaran (2003) defines population as:

"The entire group of people, events or things of interest that the researcher wishes to investigate".

For this study, the population was made up of two Libyan groups, the first being drawn from the staff of audit firms and the second being drawn from staff of industrial public companies. Within each group a further selection was made of three categories, these being auditors, managing partners and audit supervisors in the case of audit firms, and in the case of public companies, internal auditors, financial managers and accounts managers. These specific groups were chosen since earlier researches had identified that these were the most appropriate groups to use for a study of auditor independence, since their perceptions of auditor independence were highly relevant and worth consideration. These two groups are comprised of individuals who all have professional qualifications and a high degree of training and were therefore able to make informed observations that were pertinent to this area of study. The following gives the reasons why these groups have been chosen as targets.

Audit firms: who belong to the Libyan Accountants and Auditors Association (LAAA), have the right to practise as auditors and accountants, particularly, those who are registered with the General People's Committee and therefore fall under the People's control, these firms were chosen because they are employed by the government to audit the financial statements of its corporations. In this study is to meet its objective of making an examination of a number of factors that impact on perceptions of auditor independence, it is vital to be aware of audit firms' own perceptions of themselves in relation to each of the selected variables which may have an effect on auditor independence. According to the General People's Committee for the inspection and control of the People's in 2010 more than 260 firms have been registered as firms dealing with auditing and consulting.

Industrial public companies: The choice was made of Industrial public companies because they have a wide experience of dealing with auditing firms and are the longest established and biggest firms dealing with the Libyan audit market, and therefore will hold opinions relating to auditor independence since they will have contracts with external auditors who will be responsible for the auditing of their financial statements. It is therefore of significant importance to know how the staff who are part of these companies, such as internal auditors, financial managers and account managers, perceive the external auditors' independence, particular, these three classes were chosen because they have direct connection with the external auditors. The Libyan government currently owns about 121 industrial public companies.

\section{The Process of Sampling}

Once the population to be used for this study had been defined, a section of that population that could be seen as representative of the whole had to be selected, this process being known as sampling. Sekaran (2003) defined sampling as: 
"The process of selecting a sufficient number of elements from the population, so that a study of the sample and an understanding of its properties or characteristics would make it possible for us to generalise such properties or characteristics to the population elements".

Samples are used for the collection of data, rather than an entire population, because it is more manageable in terms of cost and the use of various other resources, in particular where there are a number of elements involved and they are geographically wide-spread. It is important to choose the right technique for sampling from among the range of methods that exist. Commenting on this, Collis and Hussey (2003), suggest that what makes a representative and good sample is one where the results that are collected from the sample can be relied upon to apply to the population as a whole. They also state that a good sample must be:

1) chosen at random meaning that each member within the population stands a chance of being chosen;

2) of a sufficient size to enable it to meet the needs of the investigation;

3) an unbiased sample.

Sekaran (2003) maintains that there are two main ways in which a sample may be designed. The first is probability sampling which allows for each element of a population to have a chance which is known and equal of being a selected subject, and the second is non-probability where those potentially taking part do not have a known or predetermined chance of selection. In this study probability sampling was used in order for subjects from each of the target groups, that is the staff of audit firms and the staff of public companies, to be selected. The use of a random sampling method ensures that that there is an equal probability of each person in the targeted class being selected as part of the sample. This method of sampling also makes use of non-replacement sampling so that there is no chance of choosing a specific respondent more than once. The reasons for opting to use this method are firstly that it offers greater generalisability and the sample that is most representative, and second it helps to eliminate bias which means that it is possible to make an estimation of possible sampling errors (Sekaran, 2003). Since Tripoli, the capital of Libya, Benghazi, Mosratah and Al-Zawiah are the cities where most of the financial and commercial activities of Libya take place (Khorwatt, 2006; Mahmud, 1997), these were the locations where sampling dealing with the selection of subjects from the two targeted groups took place. This was for the following reasons:

1) in excess of $80 \%$ of those audit firms registered with the General People's Committee for the People's control and inspection are located in these cities;

2) most of the economic and business activity take place here;

3) and these four cities have more than $85 \%$ of the industrial public companies in Libya.

Saunders et al. (2007) maintain that in order to have a good likelihood of obtaining a sampling distribution that is close to the norm, the sample size needs to be not less than $30 \%$. They also make the point that where a sample is of a large absolute size there is the likelihood that it will better represent the population from which it is drawn than would be the case with a smaller sample. However, Cohen and Manion (1980) take the view that it is not possible to set down an exact number or percentage that needs to be used by all studies. It has been suggested by some authors that there are a number of considerations that need to be taken into account of when deciding on the size of the sample that is to be selected, such as the nature of the statistical analysis that is to be used, and how much variability is expected within the sample and the results; these considerations should be based on experience, the conventions that exist in a particular area of research in relation to what is considered an appropriate sample size, as well as the size of the whole population and issues of time and costs (Collis \& Hussey, 2003; Saunders et al., 2007).

After due consideration being given to the issues discussed above relating to the size of the sample which, in this case, will receive questionnaires, the size of the sample to be taken from each targeted population was decided to be more than $50 \%$ of the population as follows; the first segment of the questionnaire sample involved 67 public companies and 137 audit firms working in Libya. The questionnaire was given to three different classes of public company respondents, namely, internal auditors, financial managers and accounts managers; while it was also given to three different classes of audit firm respondents, namely, managing partners, audit supervisors and auditors. The total number of questionnaires distributed to the public companies was 201; 67 questionnaires of each class in the public companies mentioned above. The total number of questionnaires distributed to audit firms working in Libya was 411; 137 questionnaires to people in each position in the audit firms listed above. On the one hand, on the demand side, the three classes in public companies were chosen because they were leaders in their company's business activities and, hence, needed a monitoring mechanism to report on their performance (Jensen \& Meckling, 1976). On the supply side, three classes of audit firms were considered because they were the main 
subjects in the issue of interest, supplying the documentation and/or information to the shareholders to evaluate for credibility (Humphrey, 1997).

According to Saunders et al. (2009) maintains that there are several structures for administering questionnaires: postal questionnaire, the delivery and collection approach, interviewer administered and questionnaire by telephone. In order to receive a high level of valid responses in the present case, the delivery and collection method was selected for gathering the data. The researcher distributed the questionnaire to the respondents and collected them again individually. This structure was meant to guarantee an adequate answer rate for the questionnaire survey. In addition, to establish contact for the interview phase later in the study, the delivery and collection method was most appropriate. Furthermore, a postal questionnaire was also sent to respondents located in far-away places outside the chosen cities. To raise the number of responses, the respondents were given the option to send their reply in a reply paid envelope, which was already included in every copy of the questionnaire that was sent out.

In the questionnaire survey, to obtain better responses, a reminder was sent to those respondents who had not yet sent in their questionnaire. This step was taken with due care and diligence, for if the researcher demonstrates inter-personal skills the respondents can become more co-operative. The total number of questionnaires completed and collected from public companies was $89 ; 28(31.5 \%)$ from the internal auditors, $31(34.9 \%)$ from the financial managers and $30(33.6 \%)$ from the accounts managers, while the total number of questionnaires completed and collected from the audit firms was 192 questionnaires; 46 (26.8\%) questionnaires from the managing partners, $52(25 \%)$ questionnaire from the audit supervisors and 94 (48.2\%) from the auditors.

\section{Results and Discussion}

\subsection{Quantitative Findings}

\section{Future Development on the Perceptions of Auditor Independence}

To establish their perceptions regarding the development of auditor independence in Libyan audit market, the respondents in public companies and audit firms were invited to specify on the rating scale ranging from, 1 strongly disagree, to 6 , strongly agree, the extent to which they agreed or disagreed with the seven statements proposed in Table 1.

According to the Table 1, the majority of the public company respondents were agreed with the statements: The percentage of NAS income for audit firms should not be higher than the percentage of audit services income, Audit firms should disclose the type and amount of NAS provided to their audit clients, Public companies should disclose the amount of audit and NAS fees paid in the annual report, Only the Big Four firms carry out the auditing of large companies and The LAAA should adopt international auditing and accounting standards to improve the perception of auditor independence. While the majority of them were disagreed with the statements: An independent body allocates audit clients to audit firms e.g. the LAAA, and A range of audit fees should be specified by an independent body e.g. the LAAA.

In Table 1, the majority of the respondents' responses of audit firms were agreed with the statements: Audit firms should disclose the type and amount of NAS provided to their audit clients, Only the Big Four firms carry out the auditing of large companies, The percentage of NAS income for audit firms should not be higher than the percentage of audit services income and The LAAA should adopt international auditing and accounting standards to improve the perception of auditor independence, while the majority of them were disagreed with the statements: An independent body should allocate audit clients to audit firms e.g. the LAAA and A range of audit fees should be specified by an independent body e.g. the LAAA.

From the previous descriptive analysis of two sides of auditing services (demand and supply) public companies and audit firms the responses of public company respondents were similar to the responses of audit firm respondents. However, in the Table 1 the analysis shows four significant differences between the answers of two groups, two significant differences at the $1 \%$ level and two significant differences at the $5 \%$ level, as measured by the Mann Whitney U test.

According to previous Table 1, the level of agreement with the statement The LAAA should adopt international auditing and accounting standards to improve the perception of auditor independence at the level $1 \%$ significance, was higher for public company respondents than audit firm respondents. Since more than half of public company respondents in this research had engaged foreign auditors as mentioned in Table 1, they are also more likely to support the view of their audit firms who prefer the implementation of International auditing and accounting standards. What is more, their companies will be more confident for the investment side when their financial statements are audited by audit firms adopting International auditing standards. 
Table 1. Respondents' opinion on ways to improve the level of perceptions of auditor independence

\begin{tabular}{|c|c|c|c|c|c|c|c|c|c|c|c|c|c|c|c|c|c|c|c|}
\hline \multirow[t]{2}{*}{ Statement } & \multicolumn{9}{|c|}{ Audit Firms staff(N=192) } & \multicolumn{9}{|c|}{ Public Companies Staff $(\mathrm{N}=89)$} & \multirow[t]{2}{*}{ Sig } \\
\hline & $\begin{array}{l}\text { SD } \\
\%\end{array}$ & $\begin{array}{c}\text { QSD } \\
\%\end{array}$ & $\mathrm{D} \%$ & $\mathrm{~A} \%$ & $\begin{array}{l}\mathrm{QS} \\
\mathrm{A} \%\end{array}$ & $\begin{array}{l}\text { SA } \\
\%\end{array}$ & $\begin{array}{l}\text { Standard } \\
\text { Deviation }\end{array}$ & $\begin{array}{l}\text { Medi } \\
\text { an }\end{array}$ & Mean & $\begin{array}{l}\text { SD } \\
\%\end{array}$ & $\begin{array}{c}\text { QSD } \\
\%\end{array}$ & $\mathrm{D} \%$ & $\mathrm{~A} \%$ & $\begin{array}{l}\mathrm{QS} \\
\mathrm{A} \%\end{array}$ & $\begin{array}{l}\text { SA } \\
\%\end{array}$ & $\begin{array}{l}\text { Standard } \\
\text { Deviation }\end{array}$ & Median & Mean & \\
\hline $\begin{array}{l}\text { 1. The percentage of NAS } \\
\text { income for audit firms should } \\
\text { not be higher than the } \\
\text { percentage of audit services } \\
\text { income. }\end{array}$ & 6.8 & 11.5 & 19.8 & 19.3 & 33.9 & 8.9 & 1.398 & 4.00 & 3.89 & 1.1 & 4.5 & 14.6 & 30.3 & 36.0 & 13.5 & 1.100 & 4.00 & 4.36 & * \\
\hline $\begin{array}{l}\text { 2. Only the Big Four firms } \\
\text { carry out the auditing of large } \\
\text { companies. }\end{array}$ & 6.8 & 5.2 & 20.3 & 30.7 & 30.2 & 6.8 & 1.264 & 4.00 & 3.93 & 2.2 & 7.9 & 37.1 & 25.8 & 24.7 & 2.2 & 1.070 & 4.00 & 3.70 & \\
\hline $\begin{array}{l}\text { 3. An independent body } \\
\text { should allocates audit clients } \\
\text { to audit firms e.g. the LAAA. }\end{array}$ & 19.3 & 15.1 & 30.2 & 24.0 & 9.4 & 2.1 & 1.316 & 3.00 & 2.95 & 18.0 & 14.6 & 32.6 & 10.1 & 15.7 & 9.0 & 1.549 & 3.00 & 3.18 & \\
\hline $\begin{array}{l}\text { 4. A range of audit fees should } \\
\text { be specified by an } \\
\text { independent body e.g. the } \\
\text { LAAA. }\end{array}$ & 14.1 & 22.4 & 19.3 & 24.5 & 15.6 & 4.2 & 1.418 & 3.00 & 3.18 & 6.7 & 21.3 & 30.3 & 24.7 & 15.7 & 1.1 & 1.190 & 3.00 & 3.25 & \\
\hline $\begin{array}{l}\text { 5.Public companies should } \\
\text { disclose the amount of audit } \\
\text { and NAS fees paid in the } \\
\text { annual report }\end{array}$ & 4.2 & 5.7 & 25.0 & 38.0 & 21.9 & 5.2 & 1.123 & 4.00 & 3.83 & 6.7 & 7.9 & 11.2 & 34.8 & 21.3 & 18.0 & 1.407 & 4.00 & 4.10 & ** \\
\hline $\begin{array}{l}\text { 6. Audit firms should disclose } \\
\text { the type and amount of NAS } \\
\text { provided to their audit clients. }\end{array}$ & 2.6 & 9.4 & 13.5 & 45.5 & 24.5 & 4.7 & 1.086 & 4.00 & 3.94 & 0 & 11.2 & 9.0 & 33.7 & 38.2 & 7.9 & 1.095 & 4.00 & 4.22 & $\# *$ \\
\hline $\begin{array}{l}\text { 7. The LAAA should adopt } \\
\text { international auditing and } \\
\text { accounting standards to } \\
\text { improve the perception of } \\
\text { auditor independence. }\end{array}$ & 2.6 & 9.4 & 27.6 & 34.4 & 21.4 & 4.7 & 1.113 & 4.00 & 3.47 & 6.7 & 9.0 & 21.3 & 41.6 & 19.1 & 2.2 & 1.160 & 4.00 & 3.64 & * \\
\hline
\end{tabular}

Note:*, ${ }^{* *}$ Indicates that the distribution of responses between the categories is significantly different at the $1 \%$ and $5 \%$ levels, respectively (using Mann Whitney U test).

\section{Future Development on the Perceptions of Auditor Independence Analysed by Type of Audit Firms}

(Local Audit Firms, Local audit firm affiliated to Arabic and International audit firm, and Local audit firm affiliated to one of the big audit firms)

More analysis was also undertaken to find out the significant differences between the three kinds of audit firms (Local Audit Firms, Local audit firm affiliated to Arabic and International audit firm, and Local audit firm affiliated to one of the big audit firms), using the Kruskal Wallis test, as reported in Table 2.

The level of agreement with the statement A range of audit fees should be specified by an independent body e.g. the LAAA, was significantly higher for local audit firm respondents than for the local audit firms affiliated to one of the big audit firm respondents at the $5 \%$ level of significance. This finding supports the finding in Table 2, which expressed the dissatisfaction of local audit firms with the audit fees paid to them, and also this result indicates more dissatisfaction among non-big four audit firms (local, Arab and International audit firms) and their desire for an independent body to identify the amount of audit fees paid to all audit companies. Furthermore, the result suggests that Big Four audit firms usually receive higher audit fees than non-Big four audit firms, and that possibly due to the level of their reputation and global reach. This outcome could point to a large premium paid to local audit firms affiliated to one of the big four audit firms, which is consistent with Palmrose (1986a) who found a premium for the big audit firms.

A further significant difference was found in the answers to the statement that Public companies should disclose the amount of audit and NAS fees paid in the annual report. With this statement the responses of local audit firms affiliated to one of big four respondents was significantly higher than local audit firms, due to the majority of local audit firms depending on a single client to obtain their income. Moreover, this result might reflect the confidence of the respondents in the potential benefits that could arise from disclosure of NAS in clients' financial statements. This finding is consistent with Lennox (1999) who investigated the effect of NAS on audit quality and found that when non-audit fees are disclosed, that may enhance auditor independence and as a result enhance audit quality. Disclosing audit and non-audit fees increases auditor independence. Hillison and Kennelley (1988) suggested that audit firms should be allowed either to provide certain NAS for audit clients or provide all types of NAS but require full disclosure. Thus full disclosure is a safeguard to reduce certain threats to auditor independence. 
Table 2. Respondents' opinion on ways to improve the level of the auditor independence analyzed by type of Audit Firms

\begin{tabular}{|c|c|c|c|c|c|c|c|c|c|c|}
\hline \multirow[t]{2}{*}{ Statement } & \multicolumn{3}{|c|}{$\begin{array}{l}\text { Local audit firms } \\
\qquad(\mathrm{N}=115)\end{array}$} & \multicolumn{3}{|c|}{$\begin{array}{l}\text { Local audit firms affiliated } \\
\text { to an Arabic and } \\
\text { Intemational audit firms } \\
\qquad \mathrm{N}=58)\end{array}$} & \multicolumn{3}{|c|}{$\begin{array}{l}\text { Local audit firms affiliated } \\
\text { to one of the Big Four audit } \\
\text { firms }(\mathrm{N}=19)\end{array}$} & \multirow[t]{2}{*}{$\mathrm{Sig}$} \\
\hline & $\begin{array}{l}\text { Standard } \\
\text { Deviation }\end{array}$ & Median & Mean & $\begin{array}{c}\text { Standard } \\
\text { Deviation }\end{array}$ & Median & Mean & $\begin{array}{c}\text { Standard } \\
\text { Deviation }\end{array}$ & Median & Mean & \\
\hline $\begin{array}{l}\text { 1. The percentage of NAS } \\
\text { income for audit firms } \\
\text { should not be higher than } \\
\text { the percentage of audit } \\
\text { services income. }\end{array}$ & 1.380 & 4.00 & 3.84 & 1.469 & 4.00 & 3.98 & 1.334 & 4.00 & 3.84 & \\
\hline $\begin{array}{l}\text { 2. Only the Big Four firms } \\
\text { should carry out the } \\
\text { auditing of large companies. }\end{array}$ & 1.139 & 4.00 & 3.62 & 1.449 & 4.00 & 3.62 & 1.250 & 5.00 & 4.32 & \\
\hline $\begin{array}{l}\text { 3. An independent body } \\
\text { should allocate audit clients } \\
\text { to audit firms e.g. the } \\
\text { LAAA. }\end{array}$ & 1.251 & 4.00 & 3.88 & 1.403 & 3.00 & 3.12 & 1.449 & 3.00 & 2.89 & \\
\hline $\begin{array}{l}\text { 4. A range of audit fees } \\
\text { should be specified by an } \\
\text { independent body e.g. the } \\
\text { LAAA. }\end{array}$ & 1.253 & 3.00 & 3.21 & 1.582 & 3.00 & 2.91 & 1.686 & 4.00 & 2.79 & $\pi \hbar$ \\
\hline $\begin{array}{l}\text { 5. Public companies should } \\
\text { disclose the amount of audit } \\
\text { and NAS fees paid in the } \\
\text { annual report }\end{array}$ & 1.077 & 3.00 & 3.08 & 1.112 & 3.50 & 3.52 & 1.224 & 5.00 & 4.53 & * \\
\hline $\begin{array}{l}\text { 6. Audit firms should } \\
\text { disclose the type and } \\
\text { amount of NAS provided to } \\
\text { their audit clients. }\end{array}$ & 1.045 & 4.00 & 3.83 & 1.170 & 4.00 & 4.00 & 0.992 & 4.00 & 4.42 & \\
\hline $\begin{array}{l}\text { 7. The LAAA should adopt } \\
\text { international auditing and } \\
\text { accounting standards to } \\
\text { improve the perception of } \\
\text { auditor independence. }\end{array}$ & 1.115 & 4.00 & 3.66 & 1.074 & 4.00 & 3.93 & 1.197 & 4.00 & 3.89 & \\
\hline
\end{tabular}

Note: *** Indicates that the distribution of responses between the categories is significantly different at the $1 \%$ and $5 \%$ levels respectively, (using Kruskal Wallis test).

\subsection{Qualitative Findings}

Table 3. Categories of organisations and the number of the interviewees and their position

\begin{tabular}{|c|c|c|c|c|c|c|c|c|}
\hline Organisation & & lic compa & & & udit firm & & LAAA & \\
\hline position & $\begin{array}{l}\text { internal } \\
\text { auditor }\end{array}$ & $\begin{array}{l}\text { financial } \\
\text { manager }\end{array}$ & $\begin{array}{l}\text { accounts } \\
\text { manager }\end{array}$ & $\begin{array}{c}\text { audit } \\
\text { supervisor }\end{array}$ & $\begin{array}{r}\text { managing } \\
\text { partner }\end{array}$ & auditor & controller & Total \\
\hline $\begin{array}{c}\text { Numberof } \\
\text { interviewees } \\
\text { Total }\end{array}$ & 3 & 3 & 1 & 4 & 3 & 4 & 3 & 21 \\
\hline
\end{tabular}

\section{Future Development on the perceptions of auditor independence in Libya}

In this section, the researcher attempted to elicit the interviewees' opinions regarding the ways to improve the level of the perceptions of auditor independence in the Libyan audit market. In the questionnaire survey results shown in Table 1 , about $64.6 \%$ of audit firm respondents and $65.2 \%$ of public company respondents either disagree or strongly disagree with the statement: An independent body should allocate audit clients to audit firms e.g., the 
LAAA. Similarly, the majority of the interviewees confirmed this result, and they observed that this can lessen competition in the audit market and that it was not adopted in developed countries. It will act as a deterrent to the ambitions of public companies to work with the audit firms which have a reputation in the market and good experience about the business type of those companies. However, most of the interviewees suggested that a representative from the LAAA should attend the Annual General Meetings of Shareholders to monitor the appointment of the external auditor, and ensure that was no manipulation by company management in selecting the external auditor.

The results of the questionnaire survey presented in Table 1, revealed that $65.1 \%$ of audit firm respondents and $74.1 \%$ of public company respondents agreed with the statement: Public companies should disclose the amount of audit and NAS fees paid in the annual report. The majority of the interviewees supported this finding, and they agreed that the disclosure of the audit and NAS fees in the clients' financial reports would enhance auditor independence. Moreover, they pointed out that the disclosure of audit and NAS in the annual reports could tell the shareholders about the amount of fees which were given to the audit firm, and then they can discuss the level with the management if it seems too high. An audit supervisor of a local audit firm affiliated to a foreign audit firm remarked:

"I think the financial statements of the companies should include the amount of audit fees because that will help to remove any doubt if there is an inappropriate personal relationship between the auditor and management, (business under the table). Another important point is that the disclosure will give a complete picture to shareholders and the general public about those fees and then can discuss that with the management if they are not satisfied with the fees."

In contrast, a minority of interviewees argued that the LAAA should establish regulations and procedures for audit firms to require them to disclose the kind and amount of NAS supplied to clients, as is the practice in developed countries.

Most interviewees believed that to improve the perception of auditor independence in the Libyan audit market the LAAA should adopt international auditing standards and accounting principles, since there are no specific local standards issued in Libya. Furthermore, most audit firms working in Libya adopt the accounting principles and auditing standards of the UK or the USA. An owner of a local audit firm pointed out:

\section{"I think adopting the accounting principles and auditing standards of the UK or USA is better than issuing new local standards, because the majority of audit firms in Libya understand and have a very good idea about those standards."}

Finally, a minority of interviewees criticised this idea and asked the LAAA to establish local standards like other developing countries, because the audit market in Libya is completely different to the market in the USA and the UK.

\section{Summary and Review of Findings}

The majority of responses from public companies staff and audit firms staff showed that the Libyan Association of Accountants and Auditors (LAAA) should adopt international auditing standards and accounting principles as an important step to improve the auditing profession and the perception of auditor independence in the Libyan audit market. Moreover, the majority of respondents had shown their dissatisfaction over allocating audit clients to audit firms by an independent body, such as the LAAA, perhaps because of respondents' desire to avoid audit firms thinking of establishing personal relationships with that body, which might have a negative effect on their reputation. Another reason for this is to give an opportunity to company management to choose the external auditor who can provide professional work and support its financial position by the auditing report. More important, the majority of public companies' and audit firms' responses revealed a preference for a law or regulation to be issued requiring public companies to disclose in their financial statements the amount of audit and non-audit service fees paid. This result recommends that this type of disclosure might identify, to interested parties, the type of association existing between the audit firm and the client.

These findings were confirmed by the majority of interviewees, especially the adoption of international accounting principles and auditing standards, rather than establishing local standards to improve auditing as a profession; it would at the same time help foreign audit firms to work in Libya without any professional difficulties. Furthermore, the interviewees showed dissatisfaction for an independent body such as the LAAA to allocate customers to audit firms, indicating that this might make the audit market in Libya less competitive, and that this action is not implemented in developed countries. 


\section{References}

Abbott, A. (1983). Profession ethics. American Journal of Sociology, 856-885.

Abu Bakar, N., Rahman, A., \& Rashid, H. (2005). Factors influencing auditor independence: Malaysian loan

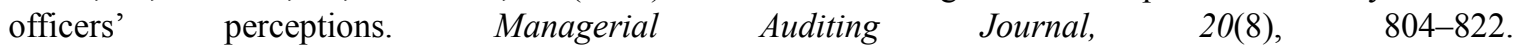
http://dx.doi.org/10.1108/02686900510619665

Bait-El-Mal, A. (2000). The role of management systems in Libya organizations: a Libyan development policy case study with special reference to the industrial sector. Unpublished $\mathrm{PhD}$ dissertation.

Bait-El-Mal, M. M., Charles, S., \& Taylor, M. (1973, Spring). The development of accounting in Libya. International Journal of Accounting education and Research, 83-102.

Cohen, L., \& Manion, L. (1980). Research methods in education (1st ed.). London: Longman.

Collis, J., \& Hussey, R. (2003). Business research (2nd ed.). Palgrave Macmillan.

Denscombe, M. (2001). Good research guide: for small-scale research projects. Buckingham, UK: Open University Press.

Higson, A. (2003). Corporate financial reporting: theory and practice. Sage Publications Ltd.

Hillison, W., \& Kennelly, M. (1988). The economics of non-audit services. Accounting Horizons, 2, 32-40.

Humphrey, C. (1997). Debating audit expectations. Current issues in auditing (3rd ed.) (pp. 3-30). London: Paul Chapman.

Jensen, M. C., \& Meckling, W. H. (1976). Theory of the Firm: Managerial Behaviour, Agency Costs and Ownership Structure. Journal of Financial Economics, 3(4), 305-360. http://dx.doi.org/10.1016/0304-405X(76)90026-X

Kilani, K. A. (1988). The evaluation and status of accounting in Libya. Unpublished PhD dissertation. Hull, UK.

Khorwatt, E. (2006). The Attitude of Libyan Auditors to Inherent and Control Risk Assessments. Unpublished $\mathrm{PhD}$ dissertation. The Manchester Metropolitan University, UK.

Lennox, C. (1999). Non-audit fees, disclosure and audit quality. European Accounting Review, 8(2), 239-252. http://dx.doi.org/10.1080/096381899336014

Mautz, R. K., \& Sharaf, H. (1961). The Philosophy of Auditing. American Accounting Association.

Mahmud, M. (1997). Accounting and economic development of oil and gas in Libya. Unpublished $\mathrm{PhD}$ dissertation. Dundee University of Dundee, UK.

Palmrose, Z. V. (1986a). Audit Fees and Auditor size: Further Evidence. Journal of Accounting Research, 24(1), 97-110. http://dx.doi.org/10.2307/2490806

Saunders, M., Lewis, P., \& Thornhill, A. (2009). Research methods for business students (5th ed.). UK: Pearson Education Limited.

Saunders, M., Lewis, P., \& Thornhill, A. (2007). Research methods for business students (3rd ed.). Prentice Hall.

Sekaran, U. (2003). Research Methods for Business: A Business: A Skill Building Approach (4th ed.). New York: John Wiley Inc.

Note

Note 1. In the UK the Companies Act 1985 requires audit firms to state in their audit report the real position of the financial reports of the client and its profit or loss.

\section{Copyrights}

Copyright for this article is retained by the author(s), with first publication rights granted to the journal.

This is an open-access article distributed under the terms and conditions of the Creative Commons Attribution license (http://creativecommons.org/licenses/by/3.0/). 